\title{
Seminoma Presenting as a Polypoid Bladder Mass: A Case Report
}

\section{Mesanede Polipoid Kitle Olarak Seminom Olgusunun Sunulması: Bir Olgu Sunumu}

\author{
Afaf ALSOLAMi ${ }^{1}$, Mohammed ALOTAIBi ${ }^{2}$, Shouki BAZARBASHiं ${ }^{3}$, Abdulmonem ALMUTAWA ${ }^{4}$, \\ Mohammed AKHTAR ${ }^{4}$
}

\begin{abstract}
'Department of Pathology and Laboratory Medicine, King Khalid University Hospital, RIYADH, KINGDOM of SAUDI ARABIA, Departments of ${ }^{2}$ Urology, ${ }^{3}$ Medical Oncology and ${ }^{4}$ Pathology and Laboratory Medicine, King Faisal Specialist Hospital and Research Centre, RIYADH,
\end{abstract} KINGDOM of SAUDI ARABIA

\begin{abstract}
We report a case of extragonadal seminoma presenting as a polypoid mass in the urinary bladder. The patient presented with two months history of hematuria. Evaluation by CT scan and cystoscopic examination revealed a polypoid mass in the base of the bladder. Biopsy of the mass revealed a classical type of seminoma. The diagnosis of seminoma was supported by strong immunostaining of the tumor cells for C-Kit and placental alkaline phosphatase. Thorough physical examination and radiologic imaging of other organ systems failed to reveal any other tumor. Both testes were found to be normal on examination and on ultrasound imaging. Patient responded well to chemotherapy. This case is unique because to the best of our knowledge there are no previously reported cases in the literature with seminoma presenting as a bladder mass.
\end{abstract}

Key Words: Seminoma, Urinary bladder, Germ cell tumors, Hematuria

\section{ÖZ}

Mesanede polipoid kitle olarak tanı alan seminom olgusu sunulmaktadır. Olgu, 2 aydır var olan hematüri yakınması ile başvurdu. Bilgisayarlı tomografi ve sistoskopide mesane tabanında polipoid kitle saptand. Kitleden alınan biyopside seminom tanısına ulaşıldı. Tanı, immünohistokimyasal olarak tümör hücrelerinin C-kit ve plasental alkalen fosfataz pozitif olması ile de desteklendi. Fiziksel muayene ve radyolojik görüntülemede başka bir tümör odağı saptanmadı. Palpasyon ve ultrasonografi ile her iki testis normaldi. Olgu kemoterapiye iyi yanıt verdi. Bu olgu, literatürde mesanede kitle ile kendini gösteren ilk seminom olgusu olması nedeni ile önem kazanmaktadır.

Anahtar Sözcükler: Seminom, Mesane, Germ hücreli tümör, Hematüri

\section{INTRODUCTION}

Extragonadal germ cell tumors (GCTs) in adults are uncommon and are mostly encountered in men. Mediastinum is the most common site of these tumors followed by retroperitoneum and central nervous system. Many of the extragonadal germ cell tumors are seminomas, although other types of germ cell tumors including embryonal carcinoma, yolk sac tumor, teratoma and mixed germ cell tumor may also be seen $(1,2)$. We hereby present a unique case of extragonadal seminoma which presented with a large polypoid intravesical mass.

\section{CASE REPORT}

A 51-year-old man presented with a history of gross hematuria for two months. The patient was obese and

(Turk Patoloji Derg 2014, 30:69-72)

Received : 20.05.2013 Accepted : 03.07.2013 a heavy smoker (2 packs per day) for the last twenty years. Patient's past medical history was unremarkable and physical examination did not reveal any significant abnormality. A computed tomography scan (CT) showed a polypoid enhancing mass measuring $35 \times 43 \mathrm{~mm}$ arising from the posterior basal aspect of the urinary bladder near the trigon, highly suggestive of urinary bladder carcinoma (Figure 1). The mass extended up to the base of the prostate but no definite intraprostatic extension was seen. Cystoscopy revealed a large polypoid mass with areas of ulceration at the bladder neck extending to the trigone. A cystoscopic biopsy was obtained, which revealed a seminoma. In view of the unusual nature of the tumor, a second cystoscopic examination was performed and additional biopsy material was obtained in order to confirm the pathologic diagnosis.

Correspondence: Mohammed AKHTAR

King Faisal Specialist Hospital and Research Centre, Department of Pathology and Laboratory Medicine (MBC-10), RIYADH, KINGDOM of SAUDI

ARABIA

E-mail: makhtar69@kfshrc.edu.sa Phone: +00966 14424235 
Both biopsies represented bladder mucosa, in which lamina propria was extensively replaced by a cellular malignant neoplasm. The overlying urothelium was focally ulcerated but otherwise uninvolved. The tumor in the lamina propria was composed of uniform round to polygonal cells with moderate to abundant partly clear cytoplasm and large nuclei with prominent nucleoli. Interspersed with the tumor cells were variable numbers of lymphocytes (Figure $2,3)$. The tumor cells were strongly immunoreactive for placental alkaline phosphatase and C-Kit (CD117) with a strong membrane staining pattern (Figure 4). There was patchy dot-like pattern of staining for CK8/18 within some of the tumor cells. The tumor cells were non-reactive for prostate specific antigen (PSA), prostatic specific acid phosphatase, CK7, CK20, CD45, CK (AE1/AE3), HMB45, S100, CD34, high molecular weight cytokeratin, epithelial membrane antigen, p63, and CD34. The tumor was

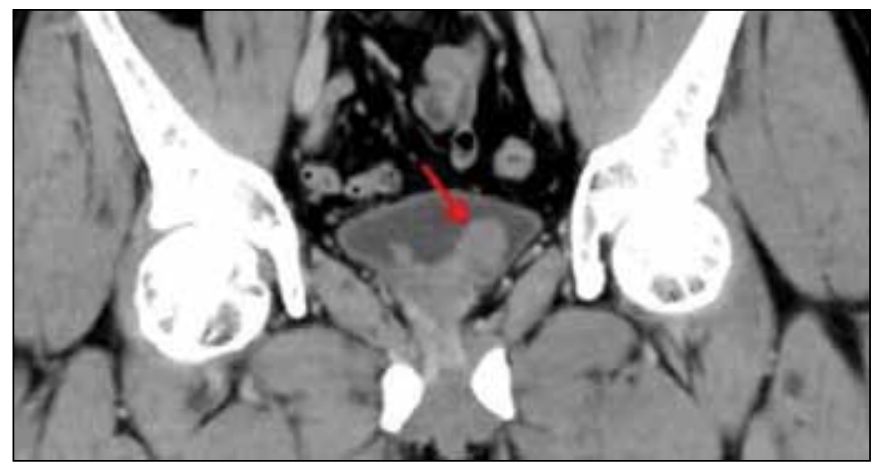

Figure 1: CT scan of the pelvic cavity showing a polypoid mass within the urinary bladder (arrow).

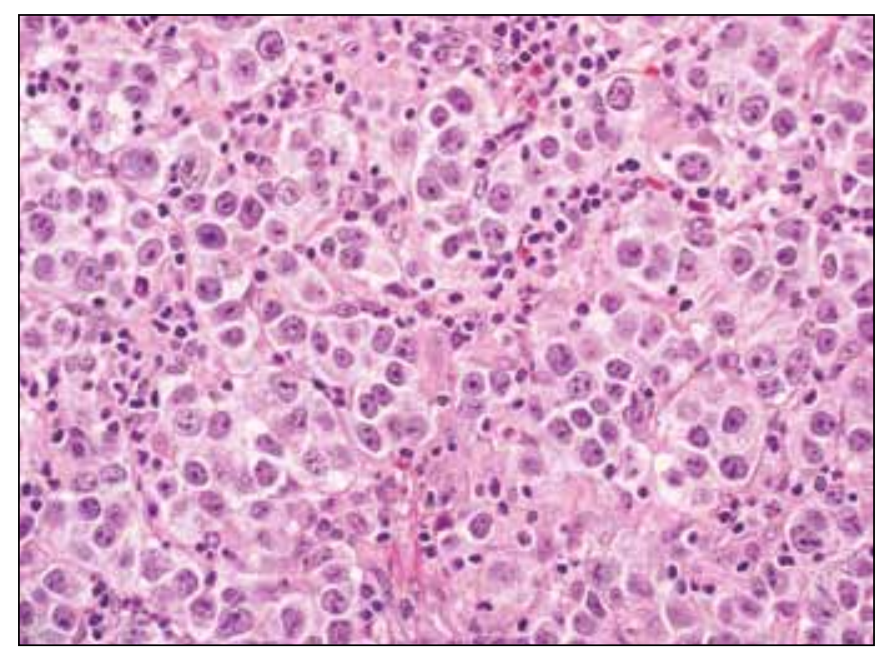

Figure 3: Higher magnification photomicrograph of the tumor depicting tumor cells with abundant partly clear cytoplasm, large nuclei and prominent nucleoli. Scattered lymphocytes are present in the background ( $\mathrm{H} \& \mathrm{E} \times 40)$. diagnosed as classical seminoma. No other germ cell tumor elements were noted.

Following the diagnosis of seminoma involving the urinary bladder, the patient was further evaluated for the presence of a primary tumor and for detection of tumor in other locations. A careful examination of both testes including ultrasound evaluation, failed to reveal any abnormal masses or calcifications. Examination by CT scan failed to reveal any masses in mediastinal or retroperitoneal spaces, abdomen and pelvis. Tumor markers including serum alpha-fetoprotein $(4.9 \mu \mathrm{g} / \mathrm{L})$, human chorionic gonadotropin (2.0 IU/L) and lactate dehydrogenase (165

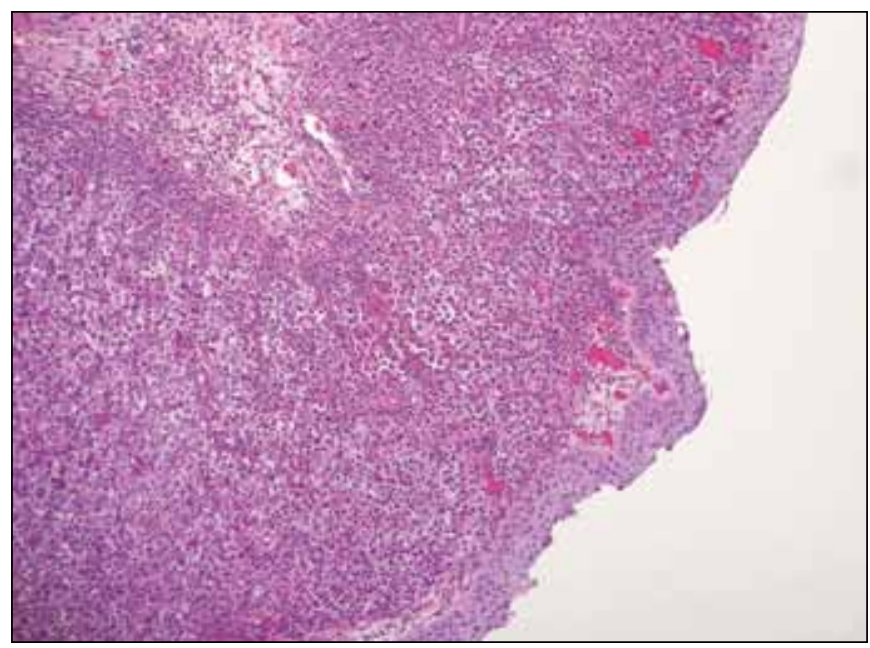

Figure 2: Bladder biopsy featuring a cellular neoplasm within the lamina propria. The tumor cells are intermixed with lymphocytes. The overlying urothelium is unremarkable (H\&E x20).

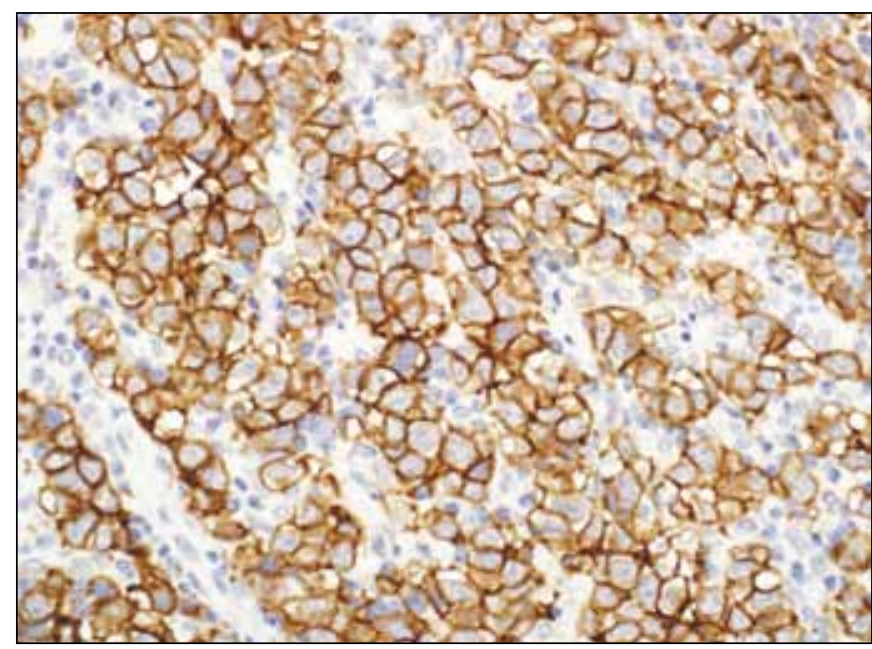

Figure 4: The tumor cells featuring strong immunohistochemical staining for C-kit (CD117) with a prominent membrane pattern (C-kit x40). 
U/L) were all in normal limits. Prostate specific antigen was $1.0 \mu \mathrm{g} / \mathrm{L}$. The patient was treated by four cycles of chemotherapy consisting of bleomycin, etoposide and cisplatin. There was a significant response with the mass shrinking to $<50 \%$ of the original size. The patient however refused further chemotherapy. A CT scan two years later revealed the bladder mass to be unchanged. There was no evidence of any metastatic focus within the abdomen, lungs or mediastinum.

\section{DISCUSSION}

Extragonadal germ cell tumors are uncommon, representing $1-5 \%$ of germ cell tumors. Their morphology varies widely and includes mature teratoma, immature teratoma, seminoma, yolk sac tumor, embryonal carcinoma and mixed germ cell tumor. Approximately $30-40 \%$ of these tumors are seminomas. Extragonadal germ cell tumors can be found anywhere on the midline, particularly the retroperitoneum, the anterior mediastinum, the sacrococcyx, and the pineal gland. The orbit, suprasellar area, palate, thyroid, submandibular region, anterior abdominal wall, stomach, liver, vagina, and prostate are the other reported less common sites $(1,2)$.

To the best of our knowledge, no cases of extragonadal germ cell tumors with presumed origin in urinary bladder have been reported. On the other hand five cases of seminoma with possible primary origin in the prostate have been documented (3-7). In all cases the tumor was a pure classical seminoma except for one case reported by Han et al (5). In that patient the tumor was a mixed germ cell tumor with predominant pattern of yolk sac tumor, while seminoma represented only a minor component. In two of the reported cases the major bulk of the tumor was in the prostate but there was extension into the bladder neck $(3,7)$. None of the tumors presented as intravesical mass. A few cases of metastatic seminoma to the prostate or bladder have been reported (8-11). In the present case the main component of the tumor was present as a polypoid intravesical mass, however the base of the tumor was adjacent to the base of the prostate without clear evidence of prostatic involvement.

Controversy remains regarding the origin of extragonadal germ cell tumors. The classical theory suggests that extra gonadal germ cell tumors are derived from local transformation of primordial germ cells misplaced during gonadal embryogenesis. The more restricted anatomical distribution of the GCTs primarily in the midline locations can probably be explained by the fact that generally the germ cells cannot survive outside the specialized niches present in testis and ovary. The occurrence of GCTs in the thymus and the midline of the brain suggest the presence of niches at those sites, which presumably offer the same support to germ cell and their neoplastic counterparts as provided by the gonads. Thymic epithelium may behave as feeder of the seminoma cells in thymus as sex cord stromal cells in the gonads (12).

An alternative theory suggests that extragonadal tumors represent migration of malignant cells from occult in situ lesions in the gonad; hence, they may be gonadal in origin. There are several reports of patients with extragonadal germ cell tumor with synchronous and metachronous germ cell tumors within the gonad (13-15). These reports emphasize the point that extragonadal germ cell tumors should be accepted as primary tumor only after a thorough evaluation of the patient to rule out a gonadal primary neoplasm. Furthermore, a prolonged follow up may also be necessary to unmask a hidden primary gonadal tumor. This indeed was the case in several reported cases in which an extragonadal tumor was initially thought to be primary, only to discover several years later that there was a gonadal germ cell tumor, which was not clinically apparent earlier (13-15). In our case, although a search for a primary tumor within the gonads has yielded negative results, such a possibility cannot be completely excluded until the patient has been followed for several years without any evidence of gonadal neoplasm or the testes have been examined for an occult or regressed germ cell tumor. Germ cell tumors in the testis are known to undergo spontaneous regression leaving only a scar as evidence of preexisting tumor $(14,16)$.

In summary, a unique case of classical seminoma presenting as a large intravesical mass is presented.

\section{REFERENCES}

1. McKenney JK, Heerema-McKenney A, Rouse RV. Extragonadal germ cell tumors: A review with emphasis on pathologic features, clinical prognostic variables, and differential diagnostic considerations. Adv Anat Pathol. 2007;14:69-92.

2. Shinagare $A B$, Jagannathan JP, Ramaiya NH, Matthew N. Hall $\mathrm{MN}$, Van den Abbeele AD. Adult extragonadal germ cell tumors. AJR. 2010;195:W274-280.

3. Khandekar JD, Holland JM, Rochester D, Christ ML. Extragonadal seminoma involving urinary bladder and arising in the prostate. Cancer. 1993;71: 3972-4.

4. Hayman R, Patel A, Fisher C, Hendry WF. Primary seminoma of the prostate. Br J Urol. 1995;76: 273-4.

5. Han G, Miura K, Takayama T, Tsutsui T. Primary prostatic endodermal sinus tumor (yolk sac tumor) combined with a small focal seminoma. Am J Surg Pathol. 2003;27: 554-9. 
6. Hashimoto T, Ohori M, Sakamoto N, Ohari M, Sakomoto N, Matsubayashi J, Izumi M, Tachibana M. Primary seminoma of the prostate. Int J Urol. 2009;16:967-70.

7. Haysaka K, Koyama M, Fukui I. FDG PET scan in a patient with primary seminoma of the prostate. Clin Nucl Med. 2011,36: 593-4.

8. Arai Y, Watanabe J, Kounami T, Tomoyoshi T. Retroperitoneal seminoma with simultaneous occurrence in the prostate. J Urol. 1988;139: 382-3.

9. Nakatani T, Sugimura K, Naganuma T, Kamikawa S, Sugimoto T. Metastatic urinary bladder tumor from extragonadal germ cell tumor: A case report. Oncol Rep. 2002;9(6):1209-11.

10. Plummer ER, Greene DR, Roberts JT. Seminoma metastatic to the prostate resulting in a rectovesical fistula. Clin Oncol. 2000; 12:229-30.

11. Viddeleer AC, Lycklama A, Nijeholt GA, Beekhuis-Brussee JA. A late manifestation of testicular seminoma in the bladder in a renal transplant recipient: A case report. J Urol. 1992;148: 401-2.
12. Oosterhuis JW, Stoop H, Honecker F, Looijenga LHJ. Why human extragonadal germ cell tumours occur in the midline of the body: Old concepts, new perspectives. Int J Androl. 2007;30:256-64.

13. Yamada Y, Tomita K, Fujimura T, Nishimatsu H, Takumi Takeuchi T, Kitamura T. Metachronous testicular tumor developing eight years after retroperitoneal extragonadal germ cell tumor. Int J Urol. 2008;15: 267-9.

14. Scholz M, Zehender M, Thalmann GN Borner M Thöni H, Studer UE. Extragonadal retroperitoneal germ cell tumor: Evidence of origin in the testis. Ann Oncol. 2002;13:121-4.

15. Rothman J, Greenberg RE, Jaffe W. Non seminomatous germ cell tumor of the testis 9 years after a germ cell of the pineal gland: Case report and review of the literature. Can J Urol. 2008; 15:4122-4.

16. Balzer BL, Ulbright TM. Spontaneous regression of testicular germ cell tumors: An analysis of 42 cases. Am J Surg Pathol. 2006; 30:858-65. 